\title{
Interview
}

\section{De grote toezichtinterviewestafette - deel 7}

\author{
DCMR Milieudienst Rijnmond
}

\author{
Marieke Gorrée en Arnt Mein*
}

Voor deze voorlopig laatste aflevering van de serie toezichtinterviewestafette spraken Arnt Mein en Marieke Gorrée namens de redactie van Tijdschrift voor Toezicht met Rosita Thé, sinds 2015 de directeur van de omgevingsdienst DCMR Milieudienst Rijnmond. Wij spraken met haar over onder andere de rapporten van de commissie-Van Aartsen en de Algemene Rekenkamer waarin vrij kritisch wordt geoordeeld over de omgevingsdiensten en het milieutoezicht, maar ook over wat het werken voor een regionale inspectie nu juist zo mooi maakt.

Arnt en Marieke: Wij willen graag beginnen met de estafettevraag van Pauline den Ambtman van de Nederlandse Voedsel- en Warenautoriteit (NVWA). Zij vroeg zich af hoe jullie omgaan met de conclusies en aanbevelingen uit het recente rapport van de commissie-Van Aartsen ${ }^{1}$ waarin staat dat de omgevingsdiensten onvoldoende capaciteit hebben om hun werk uit te voeren, er een gebrek is aan kennis en dat de omgevingsdiensten onvoldoende onafhankelijk zijn. Zij zag daarin parallellen met de NVWA maar vroeg zich ook af hoe je dit als omgevingsdiensten met elkaar adresseert. De NVWA is één organisatie, de omgevingsdiensten zijn met vele. Hoe zorg je (samen) dat je boodschap aankomt?

Rosita: Veel van de aanbevelingen van Van Aartsen herken ik. We zijn dan ook als omgevingsdiensten gezamenlijk aan de slag gegaan om die uit te werken. DCMR

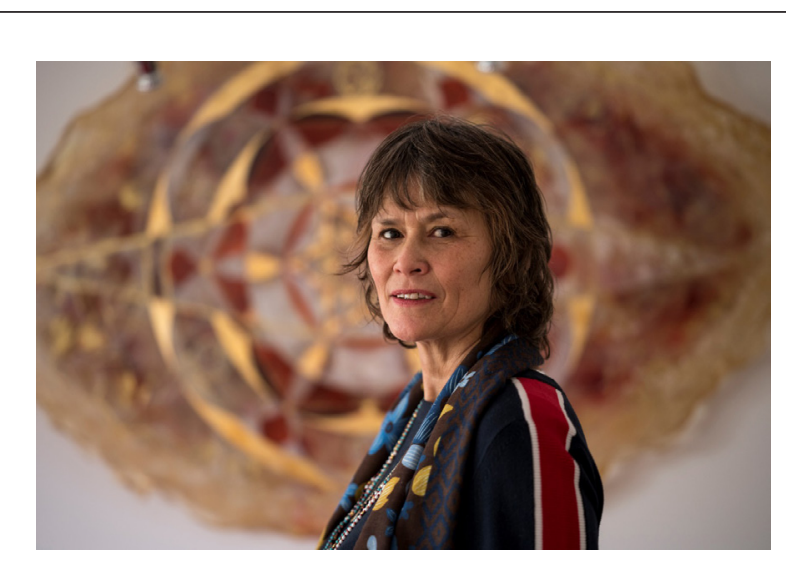

Rosita Thé is directeur van DCMR Milieudienst Rijnmond. Dit is de gezamenlijke omgevingsdienst van de provincie Zuid-Holland en vijftien gemeenten in de regio Rijnmond. DCMR zet zich in voor een schone, gezonde en veilige leefomgeving voor de 1,2 miljoen inwoners van de Rijnmondregio. Daarnaast is DCMR verantwoordelijk voor de vergunningverlening, het toezicht en de handhaving bij 140 BRZO-bedrijven ${ }^{2}$ in de provincies Zuid-Holland en Zeeland. Rosita Thé was eerder stadsdeelsecretaris in Stadsdeel West van de gemeente Amsterdam en bekleedde diverse managementfuncties bij zowel de gemeente Amsterdam als Rotterdam. 
coördineert als grootste van de BRZO-toezichthouders en met de langste staat van dienst, de onderlinge samenwerking en doet het programmamanagement voor de BRZO Omgevingsdiensten. Dat wil zeggen een gezamenlijke planning, prioriteitstelling en werkwijze. We hebben als omgevingsdiensten gezamenlijk een goed gesprek gevoerd met de commissie-Van Aartsen. Ik ben erg blij dat hun aanbevelingen zich vooral richten op verbeteringen binnen het bestaande stelsel en op niet een complete reorganisatie daarvan. Dat zou te veel afleiden.

Zo hebben we, op verzoek van het ministerie van Infrastructuur en Waterstaat (I\&W) een aanzet gedaan voor een toekomstvisie voor het VTH-stelstel. ${ }^{3}$ Om ervoor te zorgen dat er een stip op de horizon wordt gemarkeerd, waarnaar alle partners in de VTH-keten toe kunnen werken. Vervolgens zou het Rijk op dit punt de regie moeten voeren, want dit gaat voor een groot deel over beleid. We hebben een vlaggendrager nodig, dan gaan wij als uitvoerders wel lopen. Zo zijn we bijvoorbeeld hard aan de slag met datagedreven werken, maar dat kunnen we niet alleen. Daarvoor hebben we dan ook de middelen, partners en regievoering nodig.

Arnt en Marieke: Hoe krijgt dat dan concreet gestalte? Worden er bijvoorbeeld in het kader van de kabinetsformatie extra middelen vrijgemaakt voor het milieutoezicht? Kun je daar invloed op uitoefenen?

Rosita: I\&W is nu bezig met de voorbereiding van de kabinetsreactie op het rapport van de commissie-Van Aartsen. Daar spreken we wel over. Ik hoop dat daar ook in het regeerakkoord aandacht aan wordt besteed en dat middelen worden vrijgemaakt om hier een stap in te zetten. Het is heel goed mogelijk dat, tegen de tijd dat dit gesprek wordt gepubliceerd, er een passage aan is gewijd in het regeerakkoord. In de kabinetsreactie zou een aantal zaken aan de orde moeten komen. In de eerste plaats zou je over de onafhankelijkheid, basistaken en het mandaat van omgevingsdiensten landelijke afspraken willen maken samen met de bevoegde gezagen. Het is natuurlijk niet wenselijk dat dit overal verschillend is georganiseerd nu. Maar om dit meer te uniformeren moeten de VTH-diensten wel een richtpunt hebben. Ook een meer uniforme en digitale manier van vergunningverlening zou in de toekomstvisie kunnen worden opgenomen. Ideaal zou zijn als bedrijven zelf gegevens kunnen invoeren en dat die zo worden opgeslagen dat ze ook goed bruikbaar zijn voor de beantwoording van vragen en risicoanalyses. Daarbij zouden we ook veel meer aan kennisdeling kunnen doen. Wij hebben goede ervaringen opgedaan met ons toezichtlab, bijvoorbeeld als het gaat om datagestuurd werken. Zo stellen we regelmatig nalevingsanalyses op, op basis waarvan we sneller en gerichter kunnen interveniëren. We delen onze ervaringen graag met andere omgevingsdiensten.
Arnt en Marieke: Kort na Van Aartsen verscheen er ook nog een kritisch rapport van de Algemene Rekenkamer. ${ }^{4}$ Ook die was kritisch over het stelsel van toezicht en handhaving om milieucriminaliteit tegen te gaan. Jullie krijgen het wel voor de kiezen!

Rosita: Met de Algemene Rekenkamer ben ik het eens dat de kwaliteit van de informatievoorziening als basis voor het toezicht beter kan. Ook hiermee gaan we aan de slag, in samenhang met de aanbevelingen van Van Aartsen. Ik plaats wel een kritische en relativerende kanttekening bij het rapport van de Rekenkamer. Het schetst een beeld van de staat van het toezicht en de handhaving op basis van kwantitatief onderzoek aan de hand van landelijke datasystemen. Een kwalitatieve benadering naar de lokale uitvoeringspraktijk had tot uitdrukking kunnen brengen wat er zoal gedaan wordt om de effectiviteit van het toezicht te vergroten. Bijvoorbeeld het datagedreven en risicogestuurde toezicht, waarvan zij nu stellen dat dat er niet is. Dat klopt dus gewoon niet in de praktijk.

Arnt en Marieke: Nu we het toch over vergunningverlening hebben, is dat een mooi bruggetje naar de vraag van Maarten Ruys van de NVWA: Omgevingsdiensten zijn nog steeds 'VTH-diensten'. Zij verrichten taken op het gebied van vergunningverlening, toezicht en handhaving. Dat is interessant, omdat daar in het klein het spanningsveld tussen het verlenen van vergunningen en handhaven speelt. Mijn vraag is daarom: hoe manage je in je gemeente/regio die spanning als je aan de ene wethouder moet rapporteren over vergunningen, maar aan de andere wethouder moet rapporteren over het handhaven? Dit zal op papier goed werken, maar hoe werkt het in de praktijk?

Rosita: Onze positie als VTH-dienst zorgt ervoor dat er altijd sprake is van een dilemma. Maar dat maakt ons werk ook weer interessant. We hebben binnen DCMR de vergunningverlening en het toezicht en de handhaving strikt gescheiden. Het zijn twee verschillende afdelingen. Ook op bestuurlijk niveau zijn die twee taken gescheiden. Daarnaast zijn de participanten (gemeenten en Provincie) zowel eigenaar als opdrachtgever. We hebben altijd twee verschillende typen gesprekken met de gemeenten en provincies, waarbij we die over de inhoud enerzijds en over de aansturing en het beheer anderzijds strikt scheiden. Dat gaat over het algemeen vrij goed. De grondhouding bij de eigenaren is positief. Ze zeggen: DCMR is van ons. Er is altijd goed overleg, ook als het lastig wordt. Het komt wel eens voor dat we moeten optreden tegen een van de aangesloten gemeenten, bijvoorbeeld met een last onder dwangsom. De gemeenten weten daar doorgaans goed mee om te gaan. Bovendien zorgen wij ervoor dat onze inspecteurs en vergunningverleners niet in een bestuurlijk gevoelige arena hoeven te opereren. Zij moeten gewoon op basis van hun vakkennis hun werk kunnen doen en conclusies kunnen trekken. Het bestuurlijke gesprek daarover is op een an- 
der niveau in de organisatie belegd. Zo slagen we er over het algemeen goed in de verschillende taken te scheiden.

Arnt en Marieke: Even een heel ander onderwerp als het gaat om de governance van DCMR. Wij zagen op de website van de DCMR dat jullie een kinderraad hebben. Interessant, waarom zijn jullie daarmee gestart en wat levert het jullie op?

Rosita: Die kinderraad zijn we gestart omdat we behoefte hadden aan een andere en verfrissende blik. En wie kijkt er nu onbevangener en eerlijker naar de zaak dan kinderen? Ze bedenken zelf ieder jaar over welk thema ze ons willen adviseren. Zo hebben ze ons geholpen om onze website begrijpelijker te maken. En hebben ze ons geadviseerd om eens na te denken of we niet eens wat vaker bedrijven die het goed doen zouden kunnen belonen in plaats van straffen. Een idee waar we als toezichthouder zelf niet zo snel aan zouden denken.

Arnt en Marieke: Laten we een blik op de nabije toekomst richten. Welke belangrijke trends en ontwikkelingen zie je voor de komende jaren?

Rosita: We zullen als omgevingsdiensten moeten kantelen om meer toekomstbestendig te worden. Dat wil zeggen meer georiënteerd op de buitenwereld dan op onze eigen interne organisatie en disciplines. We willen bij wijze van spreken mee-ademen met onze omgeving. Daar hebben we een aantal aanknopingspunten voor. Een daarvan is het datagedreven werken, dat ik al eerder noemde. Dat zullen we verder moeten ontwikkelen. Een tweede punt is dat we meer opgavegericht moeten gaan werken. Wat vraagt de omgeving van ons en wat kunnen wij doen om daar een bijdrage aan te leveren? Een derde aanknopingspunt is de persoonlijke ontwikkeling van de medewerkers. Wat hebben zij nodig om anders te werken? Wie komt op welke plek in de organisatie het beste tot zijn of haar recht? Als oudste en grootste omgevingsdienst hebben we het voordeel dat we veel zaken in de basis al op orde hebben. We hebben dus een basis van waaruit we kunnen vernieuwen. Dat is een voordeel. Nadeel is dan soms de wet van de remmende voorsprong. Wij moeten vaak al wat oudere, bestaande systemen aanpassen, terwijl andere diensten soms direct kunnen starten met een systeem dat beter voldoet aan de huidige wensen.

Het meer opgavegericht werken willen we gaan doen door onder andere meer programmatisch te werken. We hebben op een aantal thema's programma's benoemd, zoals de circulaire economie, de energietransitie, de invoering van de Omgevingswet en complexe bedrijfsdossiers. Voor ieder programma is een programmamanager benoemd die dat op basis van zijn of haar expertise vorm en inhoud gaat geven. Opgavegericht werken betekent ook dat we coalities vormen met de rijksoverheid, gemeenten, provincies en bedrijven. Zo kunnen we vaker als adviseur betrokken zijn bij de ontwikkeling van beleid en de uitvoering daarvan, in plaats van alleen achteraf. Een mooi voorbeeld hiervan is het Rotterdamse
Circulaire loket waar ondernemers die duurzamer willen gaan ondernemen terecht kunnen met vragen. Daar leveren wij dan bijvoorbeeld kennis aan over de benodigde vergunningen. Maar zo’n coalitie kan ook kwetsbaar zijn gelet op onze rol als toezichthouder. Proactief en meer opgavegericht acteren als toezichthouder kan veel opleveren, maar we zijn en blijven toezichthouder. Dat is 'balanceren voor gevorderden', dat is onze slogan bij de werving van nieuw personeel. Ons motto voor de komende jaren is proactief en wendbaar zijn. Wendbaar wil zeggen dat we kunnen inspelen op nieuwe ontwikkelingen en dus ook investeren in de benodigde kennisopbouw. Bijvoorbeeld over ontwikkelingen als de waterstofeconomie.

Arnt en Marieke: Wat zou je als regionaal georiënteerde toezichthouder willen meegeven aan andere, landelijke toezichthouders?

Rosita: Ik zou ze op het hart willen drukken in het toezichtwerk de menselijke maat niet uit het oog te verliezen. Schenk aandacht aan burgers die zich zorgen maken over het milieu, de gezondheidszorg, het onderwijs, enzovoort. Zoek en onderhoud het contact. Leg uit, luister goed, neem omwonenden serieus. Wees reëel in wat je wel en niet kan als toezichthouder.

Zo ben ik bijvoorbeeld een kijkje gaan nemen bij inwoners die erover klaagden dat hun wasgoed dat in de tuin te drogen hing zwart werd van de uitstoot van een bedrijf in de omgeving. Dat levert niet alleen goodwill op, maar geeft mij ook gevoel bij de ervaren problematiek. Dan weet je gelijk weer waarvoor wij ons werk doen. In het verlengde daarvan, betrek burgers bij het toezicht door uitleg te geven over regelgeving en beleid en ze op te hoogte te houden van de afhandeling van hun klachten. Maar ook door hen zelf metingen te laten doen. Samen optrekken hierin dus. Uiteraard binnen de mogelijkheden. We gebruiken hiervoor onze vernieuwde website. Ik ben ervan overtuigd dat het activeren en betrekken van omwonenden, maar ook contact met de bedrijven kan leiden tot betere naleving en begrip voor elkaars situatie.

Arnt en Marieke: Hartelijk dank voor dit gesprek. 